\title{
Incidence and Etiology of Postharvest Fungal Diseases Associated with Bulb Rot in Garlic (Alllium sativum) in Spain
}

\author{
Laura Gálvez and Daniel Palmero *(D)
}

Citation: Gálvez, L.; Palmero, D. Incidence and Etiology of Postharves Fungal Diseases Associated with Bulb Rot in Garlic (Allium sativum) in Spain. Foods 2021, 10, 1063. https:/ / doi.org/10.3390/foods10051063

Academic Editor: Rinaldo Botondi

Received: 25 April 2021

Accepted: 8 May 2021

Published: 12 May 2021

Publisher's Note: MDPI stays neutral with regard to jurisdictional claims in published maps and institutional affiliations.

Copyright: (C) 2021 by the authors Licensee MDPI, Basel, Switzerland. This article is an open access article distributed under the terms and conditions of the Creative Commons Attribution (CC BY) license (https:/ / creativecommons.org/licenses/by/ $4.0 /)$.
Department of Agricultural Production, School of Agricultural, Food and Biosystems Engineering, Universidad Politécnica de Madrid, Avda. Puerta de Hierro, 4, 28040 Madrid, Spain; laura.galvez@upm.es

* Correspondence: daniel.palmero@upm.es

\begin{abstract}
In recent years, different postharvest alterations have been detected in garlic. In many cases, the symptoms are not well defined, or the etiology is unknown, which further complicates the selection of bulbs during postharvest handling. To characterize the different symptoms of bulb rot caused by fungi, garlic bulb samples were collected from six Spanish provinces in two consecutive years. Eight different fungal species were identified. The most prevalent postharvest disease was Fusarium dry rot (56.1\%), which was associated with six Fusarium species. Fusarium proliferatum was detected in more than $85 \%$ of symptomatic cloves, followed by F. oxysporum and $F$. solani. Pathogenicity tests did not show a significant correlation between virulence and mycotoxin production (fumonisins, beauvericin, and moniliformin) or the mycelial growth rate. Penicillium allii was detected in $12.2 \%$ of the samples; it was greatly influenced by the harvest season and garlic cultivar, and three different morphotypes were identified. Stemphylium vesicarium and Embellisia allii were pathogenic to wounded cloves. Some of the isolated fungal species produce highly toxic mycotoxins, which may have a negative impact on human health. This work is the first to determine the quantitative importance, pathogenicity, and virulence of the causative agents of postharvest garlic rot in Spain.
\end{abstract}

Keywords: Fusarium proliferatum; Penicillium allii; identification; pathogenicity test; virulence

\section{Introduction}

Garlic is a crop of great importance throughout the world and is highly valued for its culinary and medicinal properties. Its secondary metabolites have been shown to positively affect health and contribute to the prevention of many common human diseases, particularly through their antioxidant, anti-inflammatory, and lipid-lowering effects [1].

Spain, the first producer of garlic in Europe, has a current harvested area of 27,350 ha [2]. In recent years, garlic producers have faced new sources of postharvest losses. Diseases, pests, and poorly characterized physiological disorders cause significant postharvest garlic losses, but discriminating the symptoms of these agents remains challenging.

Postharvest rot is one of the main causes of garlic bulb loss during storage. Its incidence is directly related to the presence of pathogens on harvested bulbs and is greatly influenced by postharvest handling processes, including drying, storage, transportation, and marketing of the bulbs [3,4]. However, many pathogens initiate their infection during the development of plants in the field [5]; and the disease then progresses during the postharvest period. Some microorganisms may remain dormant and then develop during the postharvest period, causing losses of economic importance [6] or acting as inoculum reservoirs in cloves used for sowing.

The most important fungal pathogens known to cause garlic bulb rots are Sclerotium cepivorum, Penicillium spp., and Fusarium spp., which cause white rot, green rot, and dry rot, respectively $[7,8]$. Other fungal diseases are caused by Embellisia allii, Botrytis porri, and Aspergillus niger, which lead to skin blotch and black mold on garlic bulbs [9-11]. However, 
few studies have described the quantitative importance of these diseases. Dugan et al. [12] described the incidence of the fungal pathogens Aspergillus niger, A. ochraceus, Botrytis porri, Embellisia allii, Fusarium oxysporum f. sp. cepae, F. proliferatum, and Penicillium hirsutum in garlic bulbs in the United States. Valdez et al. [13] cited the importance of the green rot caused by Penicillium allii in Argentina. In Egypt, four fungal genera were detected in garlic bulbs, namely Aspergillus, Botrytis, Fusarium, and Penicillium [14], of which Fusarium spp. were the most prevalent. In a recent study conducted in Italy, F. proliferatum was the predominant fungus in bulbs infected during the postharvest period [15]. In Spain, F. proliferatum was previously described as one of the main garlic pathogens [6], but the quantitative importance of the disease that it causes in different garlic cultivars remains unknown, as does the incidence of the other fungal diseases in garlic.

Moreover, many of these fungi are known to produce a range of toxins, including fumonisins, moniliformin, beauvericin, fusaproliferin, and fusaric acid [16-18]. Most mycotoxins are chemically stable and survive food processing; therefore, they present a great risk to the health of humans and livestock [15].

In garlic dryers or the warehouses in which bulbs are selected, early detection of garlic damaged by fungi is essential to removing the disease-causing agent from the food chain. Fungal damage is usually not visible and therefore not detected during the first handling step, but postharvest diseases progress during transportation and storage, and they are the main reason that garlic bulbs are rejected by the international market. To implement successful control strategies, it is necessary to differentiate these symptoms and determine the etiology of different fungal diseases.

The objectives of this work were to (1) characterize the different types of clove rot caused by fungi and determine their quantitative importance, (2) identify the fungal microorganisms associated with different symptoms, and (3) determine the pathogenicity and virulence of isolated fungi toward non-wounded and wounded cloves.

\section{Materials and Methods}

\subsection{Plant Samples}

Garlic bulbs were collected in two consecutive harvest seasons (2013 and 2014) from different Spanish agricultural cooperatives, particularly from three provinces in the Castilla La-Mancha region (Cuenca, Albacete, and Toledo) and three provinces in the Castilla y León region (Zamora, Valladolid, and Ávila). Symptomatic bulbs of different types, including Purple Chinese (cv. Garpek), Purple Spanish (cv. Morado de Cuenca), White Spanish (cv. Garcua), and White Chinese (cv. Spring), were transported to the Plant Protection Lab (Universidad Politécnica de Madrid, Spain). In total, 1264 cloves of all types of garlic from twelve cooperatives were analyzed (Figure 1).

\subsection{Sample Processing and Description of Symptoms}

Garlic bulbs were peeled, and the cloves were separated for external visual analysis. Symptomatic cloves were then classified according to the following morphological characteristics of the lesion: color, surface appearance, contour, consistency, and the presence or absence of mycelia, as well as the color and consistency of the internal lesions.

\subsection{Fungal Isolation}

Symptomatic portions of flesh were cut from all garlic cloves that showed signs of disease. The samples were surface disinfected for $3 \mathrm{~min}$ in a $2 \%$ sodium hypochlorite solution and rinsed twice in sterile distilled water. Four small pieces cut from the margin between healthy and symptomatic tissue were plated on potato dextrose agar (PDA). The plates were incubated at $25^{\circ} \mathrm{C}$ in the dark until fungal colonies were large enough to be examined and annotated. Initial fungal isolation was performed by transferring the growing mycelia to a Petri plate containing PDA, and monosporic cultures were obtained. Isolates of $P$. allii were incubated in the dark for 7 days and morphologically characterized on Czapek yeast agar (CYA), according to Valdez et al. [13]. 


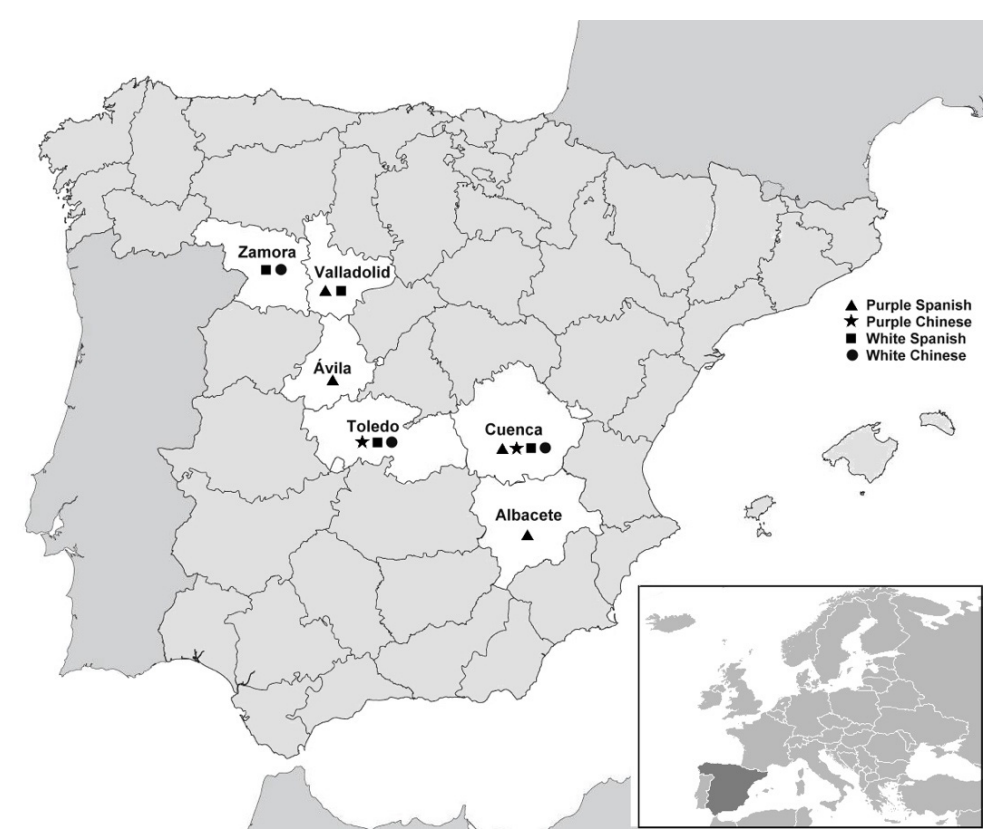

Figure 1. Map of Spain indicating the six provinces surveyed in this study (white area). The different symbols indicate the type of garlic analyzed in each province.

\subsection{Identification of Fungal Isolates}

Preliminary identifications were performed on the basis of the colony characteristics and micromorphology using a microscope and taxonomic criteria [19-26]. Identification at the species level was confirmed using molecular methods recommended for each taxonomic group. After 7 days of incubation at $25^{\circ} \mathrm{C}$ on PDA in Petri dishes, the mycelia were collected into Eppendorf tubes. DNA was extracted according to the protocol of [27]. The concentration of DNA was estimated by a NanoDrop ND-1000 spectrophotometer (NanoDrop Technologies). The ITS1-5,8S-ITS2 (ITS) region of nuclear rDNA was amplified with the primers ITS1 (5'-TCCGTAGGTGAACCTGCGG-3') and ITS4 (5'-TCCTCCGCTTATTGATATG-3'). PCR was performed using an initial cycle of denaturation at $95^{\circ} \mathrm{C}$ for $4 \mathrm{~min}, 40$ cycles of denaturation at $95^{\circ} \mathrm{C}$ for $30 \mathrm{~s}$, annealing at $50{ }^{\circ} \mathrm{C}$ for $30 \mathrm{~s}$, extension at $72{ }^{\circ} \mathrm{C}$ for $1 \mathrm{~min}$, and a final extension at $72{ }^{\circ} \mathrm{C}$ for $3 \mathrm{~min}$. Amplification of the partial $\beta$-tubulin (TUB) gene was performed using the sequence primers Bt2a (5'-GGTAACCAAATCGGTGCTGCTTTC-3') and $\mathrm{Bt} 2 \mathrm{~b}\left(5^{\prime}\right.$-ACCCTCAGTGTAGTGACCCTGGC-3') and the following PCR conditions: an initial cycle of denaturation at $94^{\circ} \mathrm{C}$ for $1 \mathrm{~min} 25 \mathrm{~s}, 32$ cycles of denaturation at $94{ }^{\circ} \mathrm{C}$ for $45 \mathrm{~s}$, annealing at $58^{\circ} \mathrm{C}$ for $55 \mathrm{~s}$, extension at $72{ }^{\circ} \mathrm{C}$ for $30 \mathrm{~s}$, and a final extension at $72{ }^{\circ} \mathrm{C}$ for $5 \mathrm{~min}$. Amplification of the partial sequence of the translation elongation factor $1 \alpha(\mathrm{EF}-1 \alpha)$ gene was performed using the primers EF1T ( $5^{\prime}$ - ATGGGTAAGGAGGACAAGAC- $\left.3^{\prime}\right)$ and EF2T (5'- GGAAGTACCAGTGATCATGTT- $3^{\prime}$ ) and the following PCR conditions: an initial cycle of denaturation at $95{ }^{\circ} \mathrm{C}$ for $1 \mathrm{~min} 25 \mathrm{~s}, 25$ cycles of denaturation at $95{ }^{\circ} \mathrm{C}$ for $35 \mathrm{~s}$, annealing at $57^{\circ} \mathrm{C}$ for $55 \mathrm{~s}$, extension at $72{ }^{\circ} \mathrm{C}$ for $1 \mathrm{~min}$, and a final extension at $72{ }^{\circ} \mathrm{C}$ for $10 \mathrm{~min}$. Amplification reactions were conducted in volumes of $25 \mu \mathrm{L}$ containing $0.8 \mu \mathrm{M}$ of each primer (Sigma-Aldrich), $0.2 \mathrm{mM}$ of each dNTP, $1 \times \mathrm{NH}_{4}$ Reaction Buffer, $2 \mathrm{mM}$ $\mathrm{MgCl}_{2}, 0.75 \mathrm{U}$ of Taq DNA polymerase (BIOTAQ, Bioline, London, UK), and $20 \mathrm{ng}$ of genomic DNA.

The PCR products were subjected to gel electrophoresis in the presence of ethidium bromide and visualized under UV light. The PCR amplicons were purified with the UltraClean ${ }^{\circledR} 15$ DNA Purification Kit (MOBIO Labs, Carlsbad, CA, USA), and sequencing was conducted using an ABI 3730xl genetic analyzer by Stab Vida Ltd. (Caparica, Portugal) in both directions with the same primers. The sequences were processed and edited using the 4Peaks program (version 1.8) and compared with the GenBank and Fusarium-ID 
databases (GenBank accession numbers corresponding to our isolates are MW244879MW245002).

\subsection{Pathogenicity Tests}

Koch's postulates were followed with 21 isolates chosen at random. For each isolate, an agar plug with a diameter of $1 \mathrm{~cm}$ was removed from the edge of 7-day-old mycelia and aseptically placed into a wound (with the same diameter and a depth of $5 \mathrm{~mm}$ ) on symptomless disinfected cloves and covered with Parafilm ${ }^{\circledR}$ (Bemis Company Inc., WY, USA). Garlic cloves inoculated with sterile agar plugs served as controls. Five garlic cloves (cv. 'Morado de Cuenca') per isolate were tested and replicated. After inoculation, the garlic cloves were packaged in plastic trays with wet filter paper and incubated at $25^{\circ} \mathrm{C}$ for $14 \mathrm{~d}$. To fulfill Koch's postulates, specimens were isolated on PDA plates in aseptic conditions after 7 days of incubation at $25^{\circ} \mathrm{C}$ from inoculated garlic cloves showing disease symptoms. The tests were conducted twice. This same experiment was conducted with non-wounded garlic cloves. For all the inoculated fungi, the disease severity index (DSI) was assessed using the clove rot index scale, which ranges from 0 to 3 (0: no symptoms; 1 : incipient surface spots of brown rot $\leq 2 \mathrm{~mm}$ in diameter; 2 : advanced coalescing brown rot spots that penetrate the clove; 3 : brown rot covers $\geq 75 \%$ of the clove surface).

\subsection{Statistical Analysis}

The incidence (average percentage of bulbs showing a specific symptom) and severity (average percentage of affected cloves showing a specific symptom per bulb) of different disorders were calculated for each garlic bulb.

The effects of the harvest season and the garlic cultivar were evaluated for each symptom using logistic regression analysis. The Wald statistic was used to determine the significance of the variables with $p \leq 0.05$. The relative frequency of each isolated fungal genus was calculated for each symptom.

The disease severity index (DSI) results were analyzed using a one-way ANOVA model with the IBM SPSS Statistics program (version 21.0), and average data were compared using Tukey's pairwise comparisons at $p \leq 0.05$.

A correlation analysis between the DSI data and the production of mycotoxins (fumonisin $\mathrm{B} 1\left(\mathrm{FB}_{1}\right)$, fumonisin $\mathrm{B} 2\left(\mathrm{FB}_{2}\right)$, fumonisin $\mathrm{B} 3\left(\mathrm{FB}_{3}\right)$, beauvericin (BEA), and moniliform $(\mathrm{MON}))$ was conducted in previous work [20], and the growth rates of 20 inoculated isolates were determined.

\section{Results}

\subsection{Observed Symptoms on Garlic Cloves}

Based on the binary logistic regression analysis (fungal isolation frequency over $80 \%$ ), represented in Table 1, three symptoms were associated with fungal species according to external and internal characteristics, as shown in Figure 2.

Table 1. Percentages of fungal genera isolated from symptomatic garlic cloves on the samples collected in two consecutive harvest seasons.

\begin{tabular}{ccccccccc}
\hline Symptom & $\boldsymbol{n}$ & Fungal Prevalence & Aspergillus & Embellisia & Fusarium & Penicillium & Rhizopus & Stemphylium \\
\hline Dry Rot & 104 & 80.8 & 0.0 & 0.0 & 76 & 5.8 & 3.8 & 0 \\
Green Rot & 32 & 81.3 & 3.1 & 0.0 & 3.1 & 78.1 & 0.0 & 0 \\
Wound Damage & 14 & 100.0 & 0.0 & 14 & 28.6 & 21.4 & 0.0 & 42.9 \\
\hline
\end{tabular}




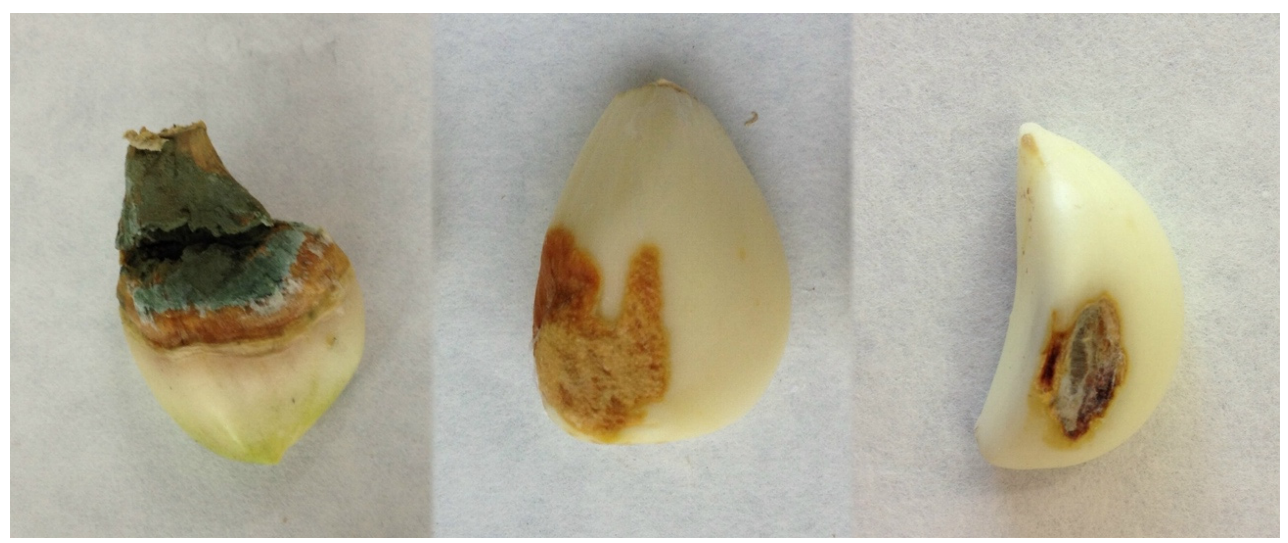

Figure 2. Symptoms associated with fungal species isolated from garlic cloves collected in Spain. Dry rot (left), green rot (middle), and wounded damage (right).

The first symptom detected, named "Dry Rot" (DR), is characterized by the presence of brown spots with a dry appearance and variable size (from less than $1 \mathrm{~mm}$ to completely covering the garlic clove), an irregular shape, and/or internal progression. The presence of white mycelia can be observed. Fusarium was isolated in $76 \%$ of the samples analyzed with this symptom (Table 1). The second symptom, named "Green Rot" (GR), is characterized by the presence of depressed yellowish spots of aqueous appearance and undefined shape. Afterward, the characteristic green mycelia were observed. Penicillum was isolated in $78.1 \%$ of these symptomatic samples (Table 1). The last symptom, named "Wound Damage" (WD), manifests as spots with variable colors and is characterized by mycelial growth, a dry appearance, and a defined contour. No internal progression was observed in the clove flesh. This symptom was associated with four fungal genera: Stemphylium, Fusarium, Embellisia, and Penicillium (Table 1).

\subsection{Incidence and Severity of Post-Harvest Fungal Diseases}

A total of 261 bulbs and 1264 garlic cloves were analyzed. The DR symptom was most frequently observed in garlic bulbs (56.1\%). The GR symptom was detected in $12.2 \%$ of the analyzed bulbs, and the WD symptom was present in $5.1 \%$ of the samples. On average, the DR symptom occurred on $20.9 \%$ of affected cloves per bulb. The severity percentages of GR and WD were $2.5 \%$ and $0.8 \%$, respectively.

The binary logistic regression analysis performed the GR for incidence data showed significant differences between seasons $(p \leq 0.001)$ and garlic cultivars (Chinese White, $p \leq 0.001$; Spanish White, $p=0.024$ ) (Table 2). This symptom was detected more frequently in the White cultivars than in the Purple cultivars.

Table 2. Percentages of symptomatic cloves (incidence means) depending on the harvest season and cultivar according to logistic regression analysis.

\begin{tabular}{|c|c|c|c|c|c|c|}
\hline \multirow[b]{2}{*}{ Symptom } & \multicolumn{2}{|c|}{ Season } & \multicolumn{4}{|c|}{ Garlic Cultivar } \\
\hline & 2013 & 2014 & $\begin{array}{l}\text { Spanish } \\
\text { Purple }\end{array}$ & $\begin{array}{l}\text { Spanish } \\
\text { White }\end{array}$ & $\begin{array}{l}\text { Chinese } \\
\text { Purple }\end{array}$ & $\begin{array}{c}\text { Chinese } \\
\text { White }\end{array}$ \\
\hline $\mathrm{GR}^{1}$ & $90.3 *$ & $9.7^{*}$ & 9.7 & $35.5^{*}$ & 16.1 & $38.7^{*}$ \\
\hline $\mathrm{DR}^{2}$ & 40.1 & 59.9 & 21 & 24.9 & 29.3 & 24.8 \\
\hline $\mathrm{WD}^{3}$ & 58.3 & 41.7 & 0 & 7.5 & 25 & 67.5 \\
\hline
\end{tabular}

\subsection{Identification of the Fungal Species Associated with Each Symptom}

Fusarium spp. was the most frequently isolated genus (76\%) from cloves with the dry rot symptom (Table 1). Fusarium proliferatum was the most predominant species $(85.5 \%)$, followed by F. oxysporum (13.2\%), F. solani ( $2.6 \%)$, F. subglutinans $(1.3 \%)$, F. redolens 
$(1.3 \%)$, and F. acuminatum (1.3\%). The F. proliferatum colonies on PDA grew white to purple mycelia and catenate microconidia (club-shaped with a flattened base, aseptate) and produced mono- and polyphialides. The curved macroconidia usually had 3-5 septates, and chlamydospores were not detected. The $E F-1 \alpha$ sequences $(\sim 710 \mathrm{bp})$ of the isolates, previously assigned to F. proliferatum according to morphological characteristics, shared 99\% identity with F. proliferatum (AF291058) based on BLASTn analysis in the Fusarium-ID database. The F. solani colonies produced sparse white to cream mycelia and oval-ellipsoid microconidia with 0 or 1 septa grouped in false heads over long monophialides. Numerous macroconidia with 5-7 septa were relatively wide, straight, stout, and robust with blunt and rounded apical cells. Chlamydospores formed individually or in pairs. The partial $E F-1 \alpha$ sequences ( 700 bp) from morphologically identified isolates showed $99 \%$ identity with F. solani (JF740714). The F. oxysporum colonies grew white to pale-violet mycelia with oval-elliptical and zero-septate microconidia were produced in false heads over short, bottle-shaped monophialides. The fusiform macroconidia had tapered and curved apical cells and foot-shaped to pointed basal cells with 3-5 septa. Chlamydospores formed individually, in pairs, or in short chains. For most of the previously identified isolates, partial EF-1 $\alpha$ sequences ( 690 bp) showed $99 \%$ identity with F. oxysporum f. sp. cepae (KP964904), but one isolate shared closer identity (99\%) with F. redolens (HQ731060). The F. acuminatum colonies produced rose mycelia and a carmine-red undersurface on PDA. Microconidia formation was not observed. The macroconidia had elongated basal cells, and 3-5 septa were formed by short phialides. Abundant macroconidia formed chains and clusters. The partial EF-1 $\alpha$ sequences $(\sim 715 \mathrm{bp})$ for these isolates shared $99 \%$ identity with $F$. acuminatum (KC175292). The F. subglutinans colonies had abundant mycelial growth, which were initially white and became violet as the culture aged. Agar pigmentation ranged from colorless to dark purple. Slightly curved macroconidia with curved apical cells and relatively poorly developed basal cells were observed. Oval and zero-septate microconidia were formed by false heads in mono- and polyphialides. The partial EF-1 $\alpha$ sequences ( 650 bp) showed 99\% identity with F. subglutinans (JF278583).

Penicillium was the most frequently isolated genus $(78.1 \%)$ associated with green rot (Table 1). Penicillium isolates produce rough, strong terverticillate conidiophores and phialides with green globose to subglobose conidia. Sclerotia were not observed. The analysis of TUB sequences ( 470 bp) showed 99\% identity with Penillium allii (HQ695995). A total of 11 isolates of $P$. allii were incubated on Czapek yeast agar (CYA) medium, and three morphotypes were differentiated by the texture of the colony, the presence of exudates, diffusible yellow pigment, and concentric furrows (Table 3).

Table 3. Morphological characteristics of the fungal colonies of $P$. allii on CYA medium after 7 days at $25{ }^{\circ} \mathrm{C}$ and their classification into different groups. The mean diameter of the mycelial colony \pm standard deviation is represented.

\begin{tabular}{ccccccc}
\hline Isolate & $\begin{array}{c}\text { Colony } \\
\text { Diameter } \\
(\mathbf{m m})\end{array}$ & Texture & Exudate & $\begin{array}{c}\text { Diffusible } \\
\text { Yellow } \\
\text { Pigment }\end{array}$ & $\begin{array}{c}\text { Concentric } \\
\text { Furrows }\end{array}$ & Group \\
\hline PA086 & $33.29 \pm 1.21$ & Granular & - & Low & Absent & 1 \\
PA088 & $17.63 \pm 0.99$ & Velvety & + & High & Present & 2 \\
PA089 & $31.97 \pm 0.79$ & Granular & + & Low & Present & 3 \\
PA090 & $32.74 \pm 0.93$ & Granular & - & Low & Absent & 1 \\
PA100 & $27.55 \pm 0.50$ & Velvety & - & Low & Present & 2 \\
PA102 & $30.54 \pm 0.64$ & Velvety & + & High & Present & 3 \\
PA112 & $27.72 \pm 0.97$ & Velvety & + & Low & Present & 3 \\
PA113 & $27.46 \pm 0.34$ & Velvety & + & Low & Present & 3 \\
PA114 & $30.83 \pm 0.83$ & Granular & + & High & Present & 3 \\
PA115 & $30.57 \pm 0.46$ & Granular & - & High & Present & 3 \\
PA130 & $21.75 \pm 0.59$ & Granular & + & Low & Absent & 1 \\
\hline
\end{tabular}


The colony diameter of all isolates ranged from 17.63 to $33.29 \mathrm{~mm}$. Morphotype 1 was characterized by a granular appearance, no production of yellow exudates, low production of diffusible yellow pigment, and the absence of concentric furrows (Figure S1). Colonies of Morphotype 2 had a velvety colony texture, small drops of yellow exudate, high production of diffusible yellow pigment, and concentric furrows. Morphotype 3 was represented by six isolates and characterized by a granular colony texture, small drops of yellow exudate, low production of diffusible yellow pigment, and concentric furrows.

Finally, a single fungus associated with wound damage symptomatology was not isolated, and the different isolated fungi never exceeded $50 \%$ of the samples analyzed. Stemphylium (42.9\%), Fusarium (28.6\%), Penicillium (21.4\%), and Embellisia (14\%) were the four fungal genera isolated for this symptom. Stemphylium vesicarium colonies were cottony with a color ranging from grayish to black with a white halo and black underside. The conidiophores were cylindrical, unbranched, and light brown with dark brown apical swelling at the site of conidium production. Mature conidia were brown, oblong, or broadly oval, with 1-3 transverse constrictions, 1-3 complete or nearly complete series of longitudinal septa, and 1-5 transverse septa. The ITS sequences showed $99 \%$ identity with Stemphylium vesicarium (LN896693). The Embellisia allii colonies presented partially superficial and immersed brown-blackish mycelia. The conidia were brown, solitary, smooth, oblong, and ellipsoid to cylindrical with 4-5 transverse septa. The conidiophores were brown, smooth, curved, and septate in groups of 3-6 solitary conidia. The ITS sequences showed 99\% identity with Embellisia allii (JN588614).

\subsection{Postharvest Pathogenicity Test on Garlic Cloves}

Garlic cloves were inoculated with the most representative isolated fungus species. A total of 28 isolates belonging to three Fusarium species were tested for their ability to cause rot in garlic cloves. Brown superficial lesions were observed on the non-wounded cloves inoculated with Fusarium spp. White mycelial growth and internal brown lesions were observed when wounded cloves were inoculated, showing the same characteristics as the original symptomatic cloves (Figure S2). Fusarium spp. caused garlic clove rot with different levels of severity in the inoculated cloves, indicated by a DSI ranging from 1 to 3 (Figure 3).

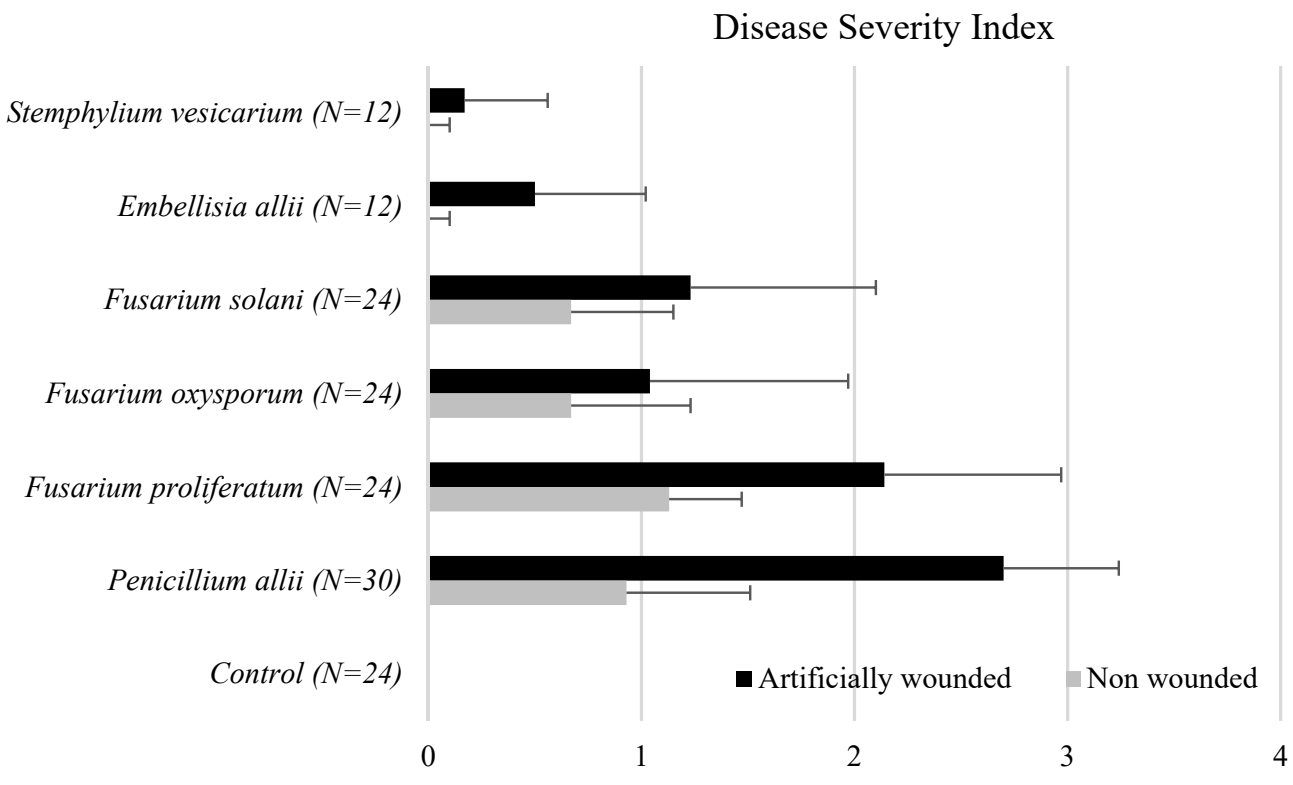

Figure 3. Disease severity index (DSI) on garlic cloves non-wounded and artificially wounded inoculated with all fungal isolates. Data (mean $\pm \mathrm{SD}$ ) for each clove garlic were graded into four classes (0-3) from no symptoms to severe rot. The same letter indicates no significant difference at $p \leq 0.05$ according to ANOVA tests. 
All isolates of $F$. proliferatum were pathogenic to garlic cloves. Fusarium proliferatum isolates showed high virulence when inoculated, and F. oxysporum and F. solani isolates were moderately virulent. The disease severity scores for F. proliferatum isolates inoculated on wounded cloves were 2.14 on average. Fusarium oxysporum and F. solani resulted in lower disease severity with means of 1.04 and 1.23, respectively. In contrast, all isolates of $F$. proliferatum were pathogens, and 11 out of 20 were highly virulent. Correlation analysis of $20 \mathrm{~F}$. proliferatum isolates did not reveal any significant correlations between the virulence (DSI), mycotoxin production $\left(\mathrm{FB}_{1}, \mathrm{FB}_{2}, \mathrm{FB}_{3}, \mathrm{BEA}\right.$, and $\left.\mathrm{MON}\right)$, and mycelial growth (mm/day) (Table 4).

Table 4. Description of the F. proliferatum isolates indicating their growth rates (mm/day), DSI values of inoculated garlic cloves and levels (in $\mu \mathrm{g} / \mathrm{g}$ ) of fumonisins $\left(\mathrm{FB}_{1}, \mathrm{FB}_{2}\right.$, and $\mathrm{FB}_{3}$ ), beauvericin (BEA), and moniliformin (MON) produced on rice grain substrate in vitro.

\begin{tabular}{cccccccc}
\hline Isolate & FB1 & FB2 & FB3 & BEA & MON & Growth Rate & DSI \\
\hline FPG05 & 749.59 & 144.82 & 45.05 & 146.09 & 57.62 & 8.34 & 1.42 \\
FPG08 & 2100.2 & 389.16 & 72.75 & 412.25 & 0.27 & 10.13 & 1.50 \\
FPG12 & 55.55 & 0.73 & 0.57 & nd & 0.98 & 5.09 & 2.17 \\
FPG16 & 8.64 & 1.36 & 0.43 & 188.48 & 11.59 & 8.09 & 1.00 \\
FPG20 & 766.74 & 127.79 & 13.58 & 429.78 & 0.44 & 9.21 & 2.09 \\
FPG21 & 2913.99 & 708.54 & 104.08 & 472.02 & 0.24 & 8.17 & 1.92 \\
FPG23 & 120.06 & 25.56 & 19.37 & 152.13 & 0.13 & 12.04 & 2.25 \\
FPG30 & 527.03 & 88.54 & 43.51 & 27.56 & 2.38 & 11.67 & 2.17 \\
FPG33 & 667.83 & 158.36 & 45.1 & 995.37 & nd & 7.80 & 2.25 \\
FPG34 & 1202.61 & 34.11 & 19.92 & 44.37 & 68.88 & 9.13 & 1.17 \\
FPG35 & 239.29 & 22.4 & 18.27 & 79.07 & 1.26 & 11.79 & 2.25 \\
FPG36 & 64.22 & 8.84 & 0.93 & nd & 4.71 & 9.13 & 0.92 \\
FPG45 & 493.51 & 62.28 & 47.07 & 187.25 & 0.37 & 12.29 & 2.21 \\
FPG58 & 1335.2 & 222.53 & 40.98 & 552.51 & 0.3 & 8.04 & 1.92 \\
FPG59 & 249.06 & 40.36 & 5.86 & 68.65 & 5.71 & 7.59 & 1.17 \\
FPG65 & 510.22 & 172.64 & 19.41 & 564.22 & 1.07 & 10.50 & 1.59 \\
FPG75 & 1.64 & 0.31 & 0.2 & 96.24 & 0.29 & 7.21 & 1.00 \\
FPG77 & 354.32 & 72.74 & 9.04 & 358.51 & 1.01 & 6.00 & 1.83 \\
FPG80 & 586.94 & 86.15 & 14.67 & 160.08 & 8.14 & 6.67 & 2.25 \\
FPG82 & 1730.23 & 216.28 & 15.96 & 596.94 & 1.87 & 9.84 & 1.42 \\
$p$ valor * & 0.804 & 0.577 & 0.252 & 0.242 & 0.158 & 0.567 & \\
\hline nd: not detected * bivariate & correlations with virulence represented by & &
\end{tabular}

nd: not detected; * bivariate correlations with virulence represented by DSI.

P. allii isolates produced small, superficial lesions on non-wounded garlic cloves. In contrast, when wounded cloves were inoculated, green mycelial growth and internal progression of the lesion were observed. Inoculations with P. allii isolates reproduced the same symptoms as the original specimen. The DSI ranged from 2.17 to 3 (Figure 3). Four out of five isolates were considered highly virulent, and Embellisia allii and S. vesicarium were pathogenic to wounded garlic cloves. Superficial mycelial growth was observed on the wounded cloves, but no internal lesions were observed.

\section{Discussion}

Postharvest rot caused by fungi strongly affects the quality of harvested garlic bulbs and produces different alterations in cloves that devalue the final product. The most frequently observed fungal diseases on harvested bulbs in Spain were primarily caused by two fungal genera: Fusarium (isolated from $76 \%$ of symptomatic garlic) and Penicillium (isolated from $78.1 \%$ of symptomatic garlic). "Wound Damage" was detected in $5.1 \%$ of the samples; however, our results indicate that this symptom is caused by trauma or injuries that occur during harvest or postharvest handling, followed by the growth of pathogenic or weakly pathogenic fungi, such as Fusarium, Penicillium, Embellisia or Stemphylium.

The appearance of the disease caused by Fusarium spp. differs depending on its evolution or environmental conditions. In the initial phase, brown lesions with a dehydrated 
appearance may emerge in different zones of the garlic clove. These spotted lesions are a few millimeters and can progress to cover the entire clove during the storage period. This disease is caused by Fusarium spp., and it is consistent with previous works by different authors $[14,15,28-30]$. In some cases, these lesions are covered with white mycelia. Moreover, this disease can be confused with the damage caused by eriophyid mites which cause a superficially dehydrated appearance that subsequently darkens and can be confused with Fusarium dry rot. Cloves affected by physiological disorders, such as waxy breakdown, turn deep yellow/amber and subsequently darken later, and they are easily confused with Fusarium dry rot. Of the postharvest symptoms observed in this study, Fusarium dry rot was detected with the highest frequency in Spain. The high incidence is consistent with Moharam et al. [14], who reported that Fusarium spp. were the most frequently isolated pathogen from garlic bulbs in the field and during storage (detected in up to $66.7 \%$ of the samples analyzed) in Egypt. In Italy, Mondani et al. [15] observed that F. proliferatum was the predominant fungus in infected bulbs (mean incidence: $35.4 \%$ ) and was confirmed to be the causal agent of rot in garlic in the postharvest period. Logistic regression analysis revealed that the harvest season and garlic cultivar had no significant effects on the incidence of this disease. Six species of Fusarium were detected on affected cloves: F. proliferatum, F. oxysporum, F. solani, F. acuminatum, F. subglutinans, and F. redolens. The most prevalent species was F. proliferatum, detected in more than $85 \%$ of symptomatic cloves, followed by F. oxysporum and F. solani. Several studies have previously cited F. proliferatum as the causal agent of garlic bulb rot in different countries such as Hungary [31], USA [29], Spain [32], Italy [30], Argentina [33], India [34], France [35], and Russia [36]. Histological observations of F. proliferatum during the early stages of infection have confirmed that it colonizes roots $72 \mathrm{~h}$ after inoculation, although it does not appear to directly penetrate healthy cells [5]. All the tested F. proliferatum isolates were pathogenic to garlic cloves, whereas some isolates of F. oxysporum and F. solani were not, consistent with Moharam et al. [14]. Fusarium oxysporum seems to play a role in infections on basal plates and roots [15]. Moreover, F. proliferatum was more virulent than F. solani and F. oxysporum for both non-wounded and wounded cloves. Variability in the virulence of F. oxysporum and F. proliferatum has also been cited for other species within the Allium genus, such as onion [37], leek, and chive [17].

Penicillium allii was previously described by Dugan [38], Valdez et al. [39], and Moharam et al. [14] as the causal of green rot disease in garlic in the United States, Argentina, and Egypt, respectively. Penicillium allii was detected in $12.2 \%$ of the samples analyzed, which is consistent with Valdez et al. [13] and Moharam et al. [14], who observed losses ranging from $8.25 \%$ to $18.18 \%$ (13.21\% on average) of harvested garlic bulbs in Argentina and Egypt, respectively. The disease was more frequently observed in White cultivars (Chinese and Spanish) than in Purple cultivars, and this incidence increased during the 2014 season. Overy et al. [40,41] cited P. allii as the most virulent fungal pathogen affecting garlic plants in the field and during subsequent storage. The comparison of the TUB gene sequences of the Spanish isolates led to the identification of $P$. allii, which comprises different morphotypes that vary in the texture of the colonies, the presence of exudates, the production of diffusible yellow pigment, and the morphology of the observed furrows. Valdez et al. [13] also described several morphotypes among P. allii. All isolates showed high virulence on previously wounded garlic cloves $[12,13,42]$. Our results show that $P$. allii was less virulent on non-wounded cloves, indicating that fungal infections require the presence of previous wounds to develop [43]. The prevention of trauma and wounds during the harvesting and subsequent handling of garlic is fundamental for effectively controlling postharvest green rot.

Stemphylium vesicarium and E. allii, characterized by the presence of dark-colored mycelia, were isolated from cloves with the "Wound Damage" symptom. Stemphylium vesicarium has been described as the causal agent of leaf blight of garlic [44,45], but its isolation from postharvest garlic cloves is described in this paper for the first time.

Embellisia allii (syn. Alternaria embellisia) has been previously reported as causing cosmetic blemishes on the outer skin layers of the bulb [46-48]. Our results show the 
presence of this pathogen on postharvest bulbs and its pathogenicity to wounded cloves. These results agree with those recently cited as causing bulb canker in garlic in Mexico [49]. Inoculation tests with both fungi confirm that they cannot penetrate the clove and cause internal rot. However, E. allii was able to grow to some extent and sporulate on the wounded surfaces of cloves. These results suggest that these wounds were caused during cultivation or harvesting and at the postharvest stage, facilitating the development of these fungi but without progressing to clove rot. Therefore, these damages should not be underestimated, as they may not only serve as a possible source of the primary inoculum but also facilitate the long-distance dispersal of propagules.

Garlic is typically propagated via seed cloves, and ensuring that materials are pathogenfree is very important for preventing the further development of diseases. Meristem culture is commonly used by growers to obtain virus-free cloves. Planting aerial bulbils might be an alternative approach to propagation with less infection by pathogens than that observed with seed cloves [50]. Fungicides and biological control might diminish the infection of fungal pathogens on postharvest bulbs [12,51,52], but the safety periods of different active ingredients, together with long postharvest periods, considerably reduce their effectiveness. On the contrary, the effect of gaseous ozone treatment during postharvest storage was recently evaluated, and the results for postharvest rot are promising [53]. These and other tools should be aimed at reducing the inoculum density to avoid the progression of diseases such as dry and green rot in garlic in Spain, the first garlic producer in the EU.

\section{Conclusions}

Fusarium proliferatum and Penicillium allii were identified as the main causal agents of postharvest fungal diseases in Spanish garlic. The most prevalent postharvest disease was Fusarium dry rot, which was primarily associated with $F$. proliferatum. To the author's knowledge, this is the first report of Fusarium solani causing Fusarium rot of garlic during storage in Spain.

Stemphylium vesicarium and Embellisia allii were also detected in the postharvest stage. The presence of these species is relevant because they are garlic pathogens and affect plants during cropping, especially S. vesicarium, the causal agent of leaf blight of garlic, and the affected garlic cloves can serve as inoculum reservoirs. Our results provide useful insights into fungal diseases in garlic bulbs and suggest mechanisms for the early detection of symptoms during the storage period. Such strategies should be implemented when possible and may be useful in preventing the progression of the disease.

\section{Patents}

This section is not mandatory but may be added if there are patents resulting from the work reported in this manuscript.

Supplementary Materials: The following are available online at https://www.mdpi.com/article/10 $.3390 /$ foods10051063/s1. Figure S1. Morphotypes of Penicillium allii isolates from garlic in Spain after 7 days at $25^{\circ} \mathrm{C}$ in the dark on Czapek yeast agar. (A) PA086, morphotype 1; (B) PA100, morphotype 2 ; (C) PA112, morphotype 3. Figure S2. Disease severity index (DSI) scale (0-3) was used to evaluate garlic clove rot for the pathogenicity test of Fusarium spp. on non-wounded (A) and artificially wounded garlic cloves (B).

Author Contributions: Conceptualization, D.P. and L.G.; methodology, D.P.; software, L.G.; validation, D.P.; formal analysis, L.G.; investigation, D.P. and L.G.; resources, D.P.; data curation, L.G.; writing — original draft preparation, D.P. and L.G.; writing—review and editing, D.P. and L.G.; visualization, L.G.; supervision, D.P.; project administration, D.P.; funding acquisition, D.P. All authors have read and agreed to the published version of the manuscript.

Funding: This work was funded by the Garlic Cooperative Coopaman SCL (Spain) project P1920290154.

Institutional Review Board Statement: Not applicable.

Informed Consent Statement: Not applicable. 


\section{Data Availability Statement: Not applicable.}

Conflicts of Interest: The authors declare no conflict of interest. The funders had no role in the design of the study; in the collection, analyses, or interpretation of data; in the writing of the manuscript, or in the decision to publish the results.

\section{References}

1. Ansary, J.; Forbes-Hernández, T.Y.; Gil, E.; Cianciosi, D.; Zhang, J.; Elexpuru-Zabaleta, M.; Simal-Gandara, J.; Giampieri, F.; Battino, M. Potential health benefit of garlic based on human intervention studies: A brief overview. Antioxidants $2020,9,619$. [CrossRef]

2. FAOSTAT. FAO Statistical Division 2019. Available online: http:/ /www.fao.org/faostat/en\#data (accessed on 17 April 2021).

3. Sivakumar, D.; Bautista-Baños, S. A review on the use of essential oils for postharvest decay control and maintenance of fruit quality during storage. Crop Prot. 2014, 64, 27-37. [CrossRef]

4. Sholberg, P.L.; Conway, W.S. Postharvest Pathology. In The Commercial Storage of Fruits, Vegetables, and Florist and Nursery Stocks, USDA-ARS Agriculture Handbook; Gross, K.C., Wang, C.Y., Saltveit, M., Eds.; United States Department of Agriculture: Washington, DC, USA, 2016; Volume 66, pp. 111-127.

5. Chretien, P.L.; Laurent, S.; Bornard, S.; Troulet, C.; El Maâtaoui, M.; Leyronas, C. Unraveling the infection process of garlic by Fusarium proliferatum, the causal agent of root rot. Phytopathol. Mediterr. 2020, 59, 285-293.

6. Palmero, D.; Gálvez, L.; García, M.; Gil-Serna, J.; Benito, S. The effects of storage duration, temperature and cultivar on the severity of garlic clove rot caused by Fusarium proliferatum. Postharvest Biol. Technol. 2013, 78, 34-39.

7. Burba, J.L. Producción de ajo. In Ediciones Instituto Nacional de Tecnología Agropecuaria; INTA EEA La Consulta: Mendoza, Argentina, 2003.

8. Piccolo, R. Enfermedades Micológicas y Bacterianas del ajo (Allium sativum). Posgrado en Horticultura. 2007. Available online: http://inta.gob.ar/sites/default/files/script-tmp-enfermedades_del_ajo.pdf (accessed on 12 January 2021).

9. Schwartz, H.F.; Mohan, S.K. Compendium of Onion and Garlic Diseases and Pests; APS Press: St. Paul, MI, USA, 2008.

10. Snowdon, A.L. Chapter 7: Bulbs. In A Color Atlas of Post-Harvest Diseases \& Disorders of Fruits $\mathcal{E}$ Vegetables; CRC Press: London, UK, 1992; Volume 2, pp. 236-261.

11. Khatoon, A.; Mohapatra, A.; Satapathy, K.B. Studies on fungi associated with stora garlic (Allium sativum). Studies 2017, 6, 19-24.

12. Dugan, F.M.; Hellier, B.C.; Lupien, S.L. Pathogenic fungi in garlic seed cloves from the United States and China, and efficacy of fungicides against pathogens in garlic germplasm in Washington State. J. Phytopathol. 2007, 155, 437-445. [CrossRef]

13. Valdez, J.G.; Makuch, M.A.; Ordovini, A.F.; Frisvad, J.C.; Overy, D.P.; Masuelli, R.; Piccolo, R.J. Identification, pathogenicity and distribution of Penicillium spp. isolated from garlic in two regions in Argentina. Plant Pathol. 2009, 58, 352-361. [CrossRef]

14. Moharam, M.H.A.; Farrag, E.S.H.; Mohamed, M.D.A. Pathogenic fungi in garlic seed cloves and first report of Fusarium proliferatum causing cloves rot of stored bulbs in upper Egypt. Arch. Phytopathol. Plant Protect. 2013, 46, 2096-2103. [CrossRef]

15. Mondani, L.; Mondani, L.; Chiusa, G.; Pietri, A.; Battilani, P. Monitoring the incidence of dry rot caused by Fusarium proliferatum in garlic at harvest and during storage. Postharvest Biol. Technol. 2021, 173, 111407. [CrossRef]

16. Tonti, S.; Mandrioli, M.; Nipoli, P.; Pisi, A.; Toschi, T.G.; Prodi, A. Detection of fumonisins in fresh and dehydrated commercial garlic. J. Agric. Food Chem. 2017, 65, 7000-7005. [CrossRef]

17. Palmero, D.; De Cara, M.; Nosir, W.; Gálvez, L.; Cruz, A.; Woodward, S.; González-Jaén, M.T.; Tello, J.C. Fusarium proliferatum isolated from garlic in Spain: Identification, toxigenic potential and pathogenicity on related Allium species. Phytopathol. Mediterr. 2012, 51, 207-218.

18. Thanushree, M.P.; Sailendri, D.; Yoha, K.S.; Moses, J.A.; Anandharamakrishnan, C. Mycotoxin contamination in food: An exposition on spices. Trends Food Sci. Technol. 2019, 93, 69-80. [CrossRef]

19. Barnett, H.L.; Hunter, B. Ilustrated Genera of Imperfect Fungi; APS Press: St. Paul, MI, USA, 1998.

20. Ellis, M.B. More Dematiaceous Hyphomycetes; CAB International: Denver, CO, USA, 1976.

21. Simmons, E.G. Perfect states of Stemphylium. Mycologia 1969, 61, 1-26. [CrossRef]

22. Simmons, E.G. Helminthosporium allii as type of a new genus. Mycologia 1971, 63, 380-386. [CrossRef]

23. Simmons, E.G. Perfect states of Stemphylium II. Sydowia 1985, 38, 284-293.

24. Simmons, E.G. Alternaria. In An Identification Manual; CBS Fungal Biodiversity Centre: Ultrercht, The Netherlands, 2007.

25. Frisvad, J.C.; Samson, R.A. Polyphasic taxonomy of Penicillium subgenus Penicillium. A guide to identification of food and air-borne terverticillate penicillia and their mycotoxins. Stud. Mycol. 2004, 49, 1-174.

26. Leslie, J.F.; Summerell, B.A. The Fusarium Laboratory Manual; Blackwell Publishing: Ames, IA, USA, 2006.

27. Querol, A.; Barrio, E.; Ramón, D. A comparative study of different methods of yeast strain characterization. Syst. Appl. Microbiol. 1992, 15, 439-446. [CrossRef]

28. Gálvez, L.; Urbaniak, M.; Waśkiewicz, A.; Stępień, L.; Palmero, D. Fusarium proliferatum—Causal agent of garlic bulb rot in Spain: Genetic variability and mycotoxin production. Food Microbiol. 2017, 67, 41-48. [CrossRef] [PubMed]

29. Dugan, F.; Hellier, B.; Lupien, S. First report of Fusarium proliferatum causing rot of garlic bulbs in North America. Plant Pathol. 2003, 52, 426. [CrossRef]

30. Tonti, S.; Prà, M.D.; Nipoti, P.; Prodi, A.; Alberti, I. First report of Fusarium proliferatum causing rot of stored garlic bulbs (Allium sativum L.) in Italy. J. Phytopathol. 2012, 160, 761-763. [CrossRef] 
31. Simey, E.I. Garlic rot caused by Fusarium proliferatum (Matsushima) Nirenferg var. minus Nirenferg in Hungary. Növényvédelem 1990, 26, 397-399.

32. Palmero, D.; De Cara, M.; Iglesias, C.; Moreno, M.; Gonzalez, N.; Tello, J. First report of Fusarium proliferatum causing rot of garlic bulbs in Spain. Plant Dis. 2010, 94, 277. [CrossRef] [PubMed]

33. Salvalaggio, A.; Ridao, A.D.C. First report of Fusarium proliferatum causing rot on garlic and onion in Argentina. Plant Dis. 2013, 97, 556. [CrossRef]

34. Sankar, N.R.; Babu, G.P. First report of Fusarium proliferatum causing rot of garlic bulbs (Allium sativum) in India. Arch. Phytopathol. Plant Protect. 2012, 1, 8. [CrossRef]

35. Leyronas, C.; Chrétien, P.L.; Troulet, C.; Duffaud, M.; Villeneuve, F.; Morris, C.; Hunyadi, H. First report of Fusarium proliferatum causing garlic clove rot in France. Plant Dis. 2018, 102, 2658. [CrossRef]

36. Anisimova, O.K.; Timofey, M.S.; Danilova, O.A.; Filyushin, M. First report of Fusarium proliferatum causing garlic clove rot in Russian Federation. Plant Dis. 2021. [CrossRef]

37. Haapalainen, M.; Latvala, S.; Kuivainen, E.; Qiu, Y.; Segerstedt, M.; Hannukkala, A. Fusarium oxysporum, F. proliferatum and F. redolens associated with basal rot of onion in Finland. Plant Pathol. 2016, 120, 112-120.

38. Dugan, F.M. Diseases and disease management in seed garlic: Problems and prospects. Am. J. Plant Sci. Biotechnol. 2007, 1, 47-51.

39. Valdez, J.G.; Makuch, M.A.; Ordovini, A.F.; Masuelli, R.W.; Overy, D.P.; Piccolo, R.J. First report of Penicillium allii as a field pathogen of garlic (Allium sativum). Plant Pathol. 2006, 55, 583. [CrossRef]

40. Overy, D.P.; Karlshøj, K.; Due, M. Low temperature growth and enzyme production in Penicillium ser. Corymbifera species, casual agents of blue mold storage rot in bulbs. J. Plant Pathol. 2005, 87, 57-63.

41. Overy, D.P.; Frisvad, J.C.; Steinmeier, U.; Thrane, U. Clarification of the agents causing blue mold storage rot upon various flower and vegetable bulbs: Implications for mycotoxin contamination. Postharvest Biol. Technol. 2005, 35, 217-221. [CrossRef]

42. Dugan, F.; Lupien, S.; Vahling-Armstrong, C.; Chastagner, G.; Schroeder, B. Host ranges of North American isolates of Penicillium causing blue mold of bulb crops. Crop Protect. 2014, 64, 129-136. [CrossRef]

43. Smalley, E.B.; Hansen, H.N. Penicillium decay of garlic. Phytopathology 1962, 52, 666-678.

44. Basallote, M.J.; Prados, A.M.; Pérez de Algaba, A.; Melero-Vara, J.M. First report in Spain of two leaf spots of garlic caused by Stemphylium vesicarium. Plant Dis. 1993, 77, 952. [CrossRef]

45. Polat, Z.; Besirli, G.; Sönmez, İ.; Yavuz, B. First report of Stemphylium leaf blight of garlic (Allium sativum) caused by Stemphylium vesicarium in Turkey. Australas. Plant Pathol. 2012, 25, 29.

46. Latha, S.; Sathyanarayana, N.; Reddy, O. Interception of Embellisia allii in garlic bulbs imported from China. Indian Phytopathol. 2011, 60, 126-127.

47. Lee, H.B.; Kim, C.J.; Yu, S.H. First report of bulb canker of garlic caused by Embellisia allii in Korea. Mycobiology 2002, 30, 240-243. [CrossRef]

48. Lee, H.B.; Magan, N. The influence of environmental factors on growth and interactions between Embellisia allii and Fusarium oxysporum f. sp. cepae isolated from garlic. Int. J. Food Microbiol. 2010, 138, 238-242. [CrossRef]

49. Delgado Ortiz, J.C.; Cema Chávez, E.; Ochoa Fuentes, Y.M.M.; Beltrán Beache, M. First report of Alternaria embellisia (syn. Embellisia allii) causing bulb canker or skin blotch on garlic in Mexico. Plant Dis. 2019, 103, 1031.

50. Dugan, F.; Lupien, S.; Hellier, B. Infection by Fusarium proliferatum in aerial garlic bulbils is strongly reduced compared to rates in seed cloves when both originate from infected bulbs. Crop Prot. 2019, 116, 43-48. [CrossRef]

51. Gálvez, L.; Marrero, M.D.; Llamas, D. In vitro and field efficacy of three fungicides against Fusarium bulb rot of garlic. Eur. J. Plant Pathol. 2017, 148, 321-328.

52. Mondani, L.; Chiusa, G.; Battilani, P. Chemical and biological control of Fusarium species involved in garlic dry rot at early crop stages. Eur. J. Plant Pathol. 2021. [CrossRef]

53. De Santis, D.; Garzoli, S.; Vettraino, A.M. Effect of gaseous ozone treatment on the aroma and clove rot by Fusarium proliferatum during garlic postharvest storage. Heliyon 2021, 7, e06634. [CrossRef] 